\title{
Ebola virus disease and critical illness
}

\author{
Aleksandra Leligdowicz ${ }^{1}$, William A. Fischer $\|^{2}$, Timothy M. Uyeki ${ }^{3}$, Thomas E. Fletcher ${ }^{4,5}$, Neill K. J. Adhikari ${ }^{1,6}$, \\ Gina Portella ${ }^{7}$, Francois Lamontagne ${ }^{8}$, Christophe Clement ${ }^{9}$, Shevin T. Jacob ${ }^{10}$, Lewis Rubinson ${ }^{11}$, \\ Abel Vanderschuren ${ }^{12}$, Jan Hajek ${ }^{13}$, Srinivas Murthy ${ }^{14}$, Mauricio Ferri, Ian Crozier ${ }^{15}$, Elhadj Ibrahima ${ }^{16}$, \\ Marie-Claire Lamah ${ }^{16}$, John S. Schieffelin ${ }^{17}$, David Brett-Major ${ }^{18}$, Daniel G. Bausch ${ }^{19}$, Nikki Shindo ${ }^{19}$, \\ Adrienne K. Chan ${ }^{20}$, Tim O'Dempsey ${ }^{21}$, Sharmistha Mishra ${ }^{22}$, Michael Jacobs ${ }^{23}$, Stuart Dickson ${ }^{24}$, \\ G. Marshall Lyon $\|^{25}$ and Robert A. Fowler ${ }^{1,6^{*}}$
}

\begin{abstract}
As of 20 May 2016 there have been 28,646 cases and 11,323 deaths resulting from the West African Ebola virus disease (EVD) outbreak reported to the World Health Organization. There continue to be sporadic flare-ups of EVD cases in West Africa.

EVD presentation is nonspecific and characterized initially by onset of fatigue, myalgias, arthralgias, headache, and fever; this is followed several days later by anorexia, nausea, vomiting, diarrhea, and abdominal pain. Anorexia and gastrointestinal losses lead to dehydration, electrolyte abnormalities, and metabolic acidosis, and, in some patients, acute kidney injury. Hypoxia and ventilation failure occurs most often with severe illness and may be exacerbated by substantial fluid requirements for intravascular volume repletion and some degree of systemic capillary leak. Although minor bleeding manifestations are common, hypovolemic and septic shock complicated by multisystem organ dysfunction appear the most frequent causes of death.

Males and females have been equally affected, with children ( $0-14$ years of age) accounting for $19 \%$, young adults (15-44 years) $58 \%$, and older adults ( $\geq 45$ years) $23 \%$ of reported cases. While the current case fatality proportion in West Africa is approximately $40 \%$, it has varied substantially over time (highest near the outbreak onset) according to available resources (40-90\% mortality in West Africa compared to under $20 \%$ in Western Europe and the USA), by age (near universal among neonates and high among older adults), and by Ebola viral load at admission.

While there is no Ebola virus-specific therapy proven to be effective in clinical trials, mortality has been dramatically lower among EVD patients managed with supportive intensive care in highly resourced settings, allowing for the avoidance of hypovolemia, correction of electrolyte and metabolic abnormalities, and the provision of oxygen, ventilation, vasopressors, and dialysis when indicated. This experience emphasizes that, in addition to evaluating specific medical treatments, improving the global capacity to provide supportive critical care to patients with EVD may be the greatest opportunity to improve patient outcomes.
\end{abstract}

Keywords: Ebola, Critical care

\footnotetext{
* Correspondence: rob.fowler@sunnybrook.ca

${ }^{1}$ Interdepartmental Division of Critical Care, University of Toronto, Toronto, ON, Canada

${ }^{6}$ Department of Critical Care Medicine, Sunnybrook Health Sciences Centre, Toronto, ON, Canada

Full list of author information is available at the end of the article
} 


\section{Background}

In December 2013, transmission of Zaire ebolavirus (Ebola virus (EBOV)) to humans occurred in southeastern Guinea [1], spreading to Liberia and Sierra Leone and rapidly surpassing the cumulative total of previous Ebola virus disease (EVD) outbreaks [2, 3]. Prior outbreaks occurred primarily in remote, resource-challenged settings, with case fatality proportions of 50-88 \% [4]. This current outbreak, due to its size and spread in West Africa, in addition to exported and medically evacuated cases to Europe and North America, has engaged a much broader health worker community, including critical care clinicians. While the clinical manifestations, duration of illness, and transmissibility appear similar to previous EVD outbreaks [1, 5-9], with the availability and provision of advanced supportive care in Europe and North America, mortality was less than $20 \%$, emphasizing the potential importance of supportive and critical care in the management of EVD patients. This review provides an up-to-date examination of EVD using the knowledge gained during the 2013-2016 West African outbreak to highlight relevance for the critical care physician.

\section{Viral hemorrhagic fevers}

Viral hemorrhagic fever describes the syndrome of acute severe febrile illness caused by over 30 viruses from four different taxonomic families-Filoviridae, Arenaviridae, Bunyaviridae, and Flaviviridae. Although they differ in disease epidemiology, transmission, and pathogenesis, most of these RNA viruses are zoonotic and cause nonspecific symptoms including fever, headache, weakness, vomiting, and diarrhea. Infection with filoviruses, including Marburg and Ebola viruses, can be associated with a rapid progression to hemodynamic instability, shock, and multiorgan dysfunction $[4,8]$.

Filoviruses were discovered in 1967 when 31 laboratory workers became ill after coming into contact with green monkeys imported from Africa [10]. The newly discovered virus killed $23 \%$ of infected workers in the German town of Marburg. Ebola virus was discovered in 1976 during simultaneous outbreaks in Zaire and Sudan in which $88 \%$ and $53 \%$ of patients died, respectively $[2,11,12]$. Since its discovery there have been approximately 25 EVD outbreaks [3].

\section{Epidemiology}

The West African EVD outbreak was first recognized in March 2014 in the forested region of southeastern Guinea. However, the first EVD case may have happened as early as December 2013 with zoonotic transmission of EBOV from an animal to a human, and subsequent human-to-human spread [1]. Transmission was likely well underway throughout West Africa in the spring of 2014 [13]. By June 2014 there were a few hundred confirmed or probable EVD cases, 3000 by the end of August-outstripping the ability of providers at existing Ebola treatment units to isolate and care for patients-and eventually over 20,000 cases by the end of December 2014 [14]. As of 20 May 2016 there have been 28,610 reported confirmed, probable, and suspected EVD cases and 11,308 deaths in Guinea, Sierra Leone and Liberia [15]. Another 36 cases have primarily received care in Mali, Senegal, and Nigeria as well as countries outside Africa including the USA, UK, Germany, Spain, France, Italy, the Netherlands, Norway, and Switzerland (Table 1) (Additional file 1). EVD cases in West Africa have been reported equally among males and females, with children (0-14 years of age) accounting for $19 \%$, young adults (15-44 years) $58 \%$, and older adults ( $\geq 45$ years) $23 \%$ of reported cases $[5,6,16]$.

\section{Characteristics of transmission}

Person-to-person transmission of EBOV occurs through mucous membrane contact with bodily fluids (e.g., vomit, feces, and blood) from those who are infected and symptomatic or by touching the body of someone who died of EVD [17]. Droplet transmission is less likely to occur due to low prevalence of respiratory symptoms $[16,18]$. While there are animal transmission models of aerosolized EBOV $[19,20]$, the clinical relevance of small particle droplet nuclei transmission is unclear and may only apply to the care of critically ill patients undergoing aerosol-generating procedures (intubation and ventilation, bronchoscopy) [18]. Percutaneous transmission with sharps (needle-stick, glass-related exposure) contaminated with infected bodily fluids is thought to be a very efficient mechanism of Ebola virus transmission [11].

\section{Infection prevention and control practices}

The concern about EBOV transmission has positioned infection prevention and control (IPC) at the center of clinical care. Theoretically, meticulous provision of contact precautions (hand washing, the use of gloves and a gown along with protection against mucus membrane (eyes, nose, and mouth) exposure, and proper donning and doffing of all personal protective equipment (PPE)) should be sufficient to prevent nosocomial EBOV transmission. In nonclimate-controlled West African Ebola treatment facilities (Fig. 1), the heat and humidity prevent optimal functioning of medical masks and some duckbill N-95 respirators (humidity and sweat cause them to sag and collapse). Tight fitting goggles often fog, reducing visibility. Face shields afford improved visibility but must provide sufficient coverage without risk of splash-related facial exposure. Half-sphere, semi-rigid respirators tend to be more resistant to moisture-related collapse and deformation. However, concern about the high mortality of EVD has led to IPC and PPE choices in the field that sometimes do not follow traditional 
Table 1 Chronological demographic description of 27 Ebola virus disease patients treated outside West Africa (August 2014-May 2015)

\begin{tabular}{|c|c|c|c|c|c|c|c|}
\hline & $\begin{array}{l}\text { Age } \\
\text { (years) }\end{array}$ & Occupation & $\begin{array}{l}\text { Country where Ebola } \\
\text { virus infection occurred }\end{array}$ & Case presentation & Country of Hospitalisation & $\begin{array}{l}\text { Hospital LOS } \\
\text { (days) }\end{array}$ & Outcome \\
\hline $1^{a}$ & 33 & Health worker & Liberia & Medically evacuated & USA & 19 & Survived \\
\hline $2^{\mathrm{a}}$ & 59 & Health worker & Liberia & Medically evacuated & USA & 14 & Survived \\
\hline 3 & 75 & Non health worker & Liberia & Medically evacuated & Spain & 5 & Died \\
\hline 4 & 29 & Health worker & Sierra Leone & Medically evacuated & UK & 10 & Survived \\
\hline $5^{a}$ & 36 & Health worker & Sierra Leone & Medically evacuated & Germany & 30 & Survived \\
\hline $6^{\mathrm{a}}$ & 51 & Health worker & Liberia & Medically evacuated & USA & 20 & Survived \\
\hline $7^{\mathrm{a}}$ & 43 & Health worker & Sierra Leone & Medically evacuated & USA & 41 & Survived \\
\hline 8 & $\mathrm{~N} / \mathrm{A}$ & Health worker & Liberia & Medically evacuated & France & 16 & Survived \\
\hline 9 & 70 & Nonhealth worker & Sierra Leone & Medically evacuated & Spain & 3 & Died \\
\hline $10^{\mathrm{a}}$ & 45 & Unknown & Liberia & Imported infection & USA & 8 & Died \\
\hline $11^{\mathrm{a}}$ & 38 & Health worker & Sierra Leone & Medically evacuated & Germany & 47 & Survived \\
\hline $12^{\mathrm{a}}$ & 44 & Health worker & Spain & Secondary infection & Spain & 30 & Survived \\
\hline $13^{\mathrm{a}}$ & 33 & Nonhealth worker & Liberia & Medically evacuated & USA & 16 & Survived \\
\hline 14 & 30 & Health worker & Sierra Leone & Medically evacuated & Norway & 13 & Survived \\
\hline 15 & 56 & Health worker & Liberia & Medically evacuated & Germany & 6 & Died \\
\hline $16^{\mathrm{a}}$ & 26 & Health worker & USA & Secondary infection & USA & 13 & Survived \\
\hline $17^{\mathrm{a}}$ & 29 & Health worker & USA & Secondary infection & USA & 14 & Survived \\
\hline 18 & 33 & Health worker & Guinea & Imported infection & USA & 19 & Survived \\
\hline 19 & N/A & Nonhealth worker & Sierra Leone & Medically evacuated & France & 21 & Survived \\
\hline $20^{\mathrm{a}}$ & 44 & Health worker & Sierra Leone & Medically evacuated & USA & 2 & Died \\
\hline $21^{\mathrm{a}}$ & 43 & Health worker & Sierra Leone & Medically evacuated & Switzerland & 15 & Survived \\
\hline 22 & 50 & Health worker & Sierra Leone & Medically evacuated & Italy & 38 & Survived \\
\hline 23 & N/A & Nonhealth worker & Liberia & Medically evacuated & Netherlands & 13 & Survived \\
\hline 24 & 39 & Health worker & Sierra Leone & Imported infection & UK & 25 & Survived \\
\hline 25 & 25 & Health worker & Sierra Leone & Medically evacuated & UK & 15 & Survived \\
\hline 26 & N/A & Health worker & Sierra Leone & Medically evacuated & USA & 27 & Survived \\
\hline 27 & $\mathrm{~N} / \mathrm{A}$ & Health worker & Sierra Leone & Imported infection & Italy & 31 & Survived \\
\hline
\end{tabular}

${ }^{a}$ Medical management (including utilization of invasive therapies) is described in peer-reviewed format (Table 3) and in reference [40] LOS length of stay (days), N/A not available

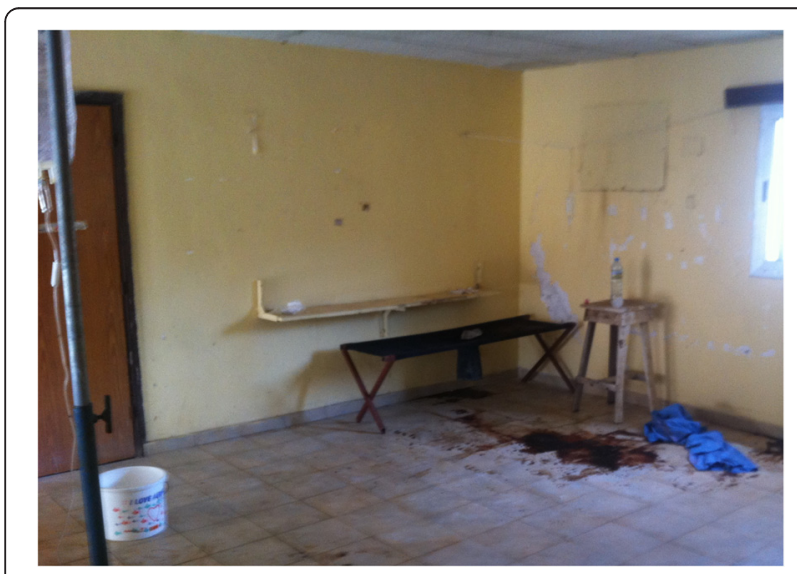

Fig. 1 West African Ebola Treatment Facility—April 2014 infection control recommendations or guidance from international technical organizations. This has often resulted in PPE that cannot be safely tolerated by healthcare personnel for more than 45-60 $\mathrm{min}$ due to excessive heat and humidity [21], risking syncope, potentially dangerous behaviour (e.g., adjusting fogged facial protection with soiled gloves), and inability to safely perform tasks such as insertion of intravenous catheters. In West Africa, Ebola virus transmission likely also occurs among healthcare personnel during informal healthcare provision in the community to patients or colleagues, without appropriate infection prevention and control practice [22, 23]. Nosocomial EBOV transmission in Spain [24, 25] and the USA [26] similarly reinforces the importance of rigorous Ebola IPC practices and healthcare personnel training, irrespective of the healthcare system $[27,28]$. 


\section{Pathophysiology}

The pathogenesis of EVD in humans remains poorly understood but shows similarities with, and differences from, other causes of viral hemorrhagic fever or bacterial sepsis. End-organ dysfunction seems to result from a combination of a direct viral cytopathic effect, the host immune response, and from under-resuscitated hypovolemic shock [5, 6]. EBOV binds to lectins and other surface receptors, with monocytes, macrophages, and dendritic cells as targets. These virus-containing cells spread through the lymphatic system, liver, and spleen, resulting in a widely disseminated viral infection $[29,30]$. Endothelial cell infection and activation may lead to increased levels of soluble adhesion molecules, thombomodulin, and inflammatory mediators such as interferon-gamma and -alpha, interleukins (IL)-2, 6, and 10, interferon-inducible proteins, and tumor necrosis factor alpha [29, 30], resulting in vascular injury.

Thrombocytopenia, consumption, and reduced production of clotting factors, in addition to increased concentrations of fibrin degradation products in patients with severe EVD, may contribute to bleeding $[29,30]$. Hepatocellular inflammation is common, and myositis with elevations of creatine kinase and pancreatitis (elevated blood amylase and lipase levels) occurs in severe cases $[29,30]$.

While acute kidney injury can often be explained by under-resuscitated hypovolemia, it might also arise from viral or secondary bacterial sepsis, acute tubular necrosis, myoglobinuria, and microvascular renal thrombi associated with sepsis or disseminated intravascular coagulation $[29,30]$. Adrenal gland viral infection has been shown in animal models and might contribute to hypotension, renal sodium loss, and hypovolemia [30].

\section{Diagnostics}

Diagnostic testing is recommended when a patient exhibits symptoms meeting the EVD case definition [31]. Ebola viral RNA can be detected in clinical specimens by real-time reverse transcription polymerase chain reaction (RT-PCR); if the virus is detected by a specific antigen diagnostic test or by detection of IgM antibodies directed against EBOV, RT-PCR should be used for confirmation [31, 32]. Because the sensitivity of molecular tests depends on Ebola viral loads, specimens collected within 3 days of symptom onset may be falsely negative due to undetectable viremia early in the clinical course. In these circumstances, another blood specimen for RT-PCR testing should be collected 3 days after symptom onset [33]. Point-of-care rapid diagnostic tests (RDTs) have been tested in the field, but they lack sensitivity, require a cold chain, and remain under evaluation in clinical trials [34].

\section{Clinical presentation of Ebola virus disease}

The clinical presentation of EVD falls along a spectrum ranging from minimally symptomatic infection [8] to severe illness with hemorrhagic complications, shock, multiorgan dysfunction, and death. The incubation period ranges from 2 to 21 days but may depend on the mode of transmission [4]: 5-7 days following a percutaneous inoculation and a mean of 9 days following direct mucus membrane contact with infected bodily fluids [8, 30, 35]. EVD typically begins with nonspecific initial signs and symptoms including fever, fatigue, weakness, and headache, similar to many infectious diseases in sub-Saharan Africa, often leading to a missed diagnosis and continued transmission. A fleeting maculopapular rash can be seen within the first week [36, 37]. Gastrointestinal symptoms (nausea, vomiting, abdominal pain, and diarrhea) usually follow 4-6 days after illness onset and can lead to hypovolemia and shock with multisystem organ dysfunction. Gastrointestinal losses and anorexia can precipitate hypokalemia, metabolic acidosis, and acute kidney injury [6]. Hypoxia and ventilation failure tend to occur with severe illness and may be exacerbated by vascular injury and accompanying large-volume fluid requirements [38]. Serious hemorrhagic complications are relatively rare, while more mild bleeding may occur in approximately $30 \%$ of cases [5, 6, 9, 16, 39, 40]. Delirium and encephalopathy or encephalitis may reflect metabolic encephalopathy or direct neuroinvasion and hiccups may be of central or peripheral neurological origin $[5,30,41,42]$.

\section{Clinical outcomes}

While the cumulative case fatality proportion in West Africa is approximately $40 \%$ as of May 2016, it has varied substantially during the course of the outbreak (being higher near the beginning). In comparison, the cumulative case fatality proportion for patients treated in Western Europe and the USA during 2014-2015 was $18.5 \%$ [40] (Table 2). Case fatality remains highest among young children and older adults [5, 6, 16, 43]. Pregnant women often experience spontaneous abortion

Table 2 Demographic and outcome summary of 27 Ebola virus disease patients treated outside West Africa

\begin{tabular}{llll}
\hline & All & Survived & Died \\
\hline Treated outside West Africa & 27 & $22(81.5 \%)$ & $5(18.5 \%)$ \\
Gender $^{\mathrm{a}}$ (male) & $17(68 \%)$ & $12(60 \%)$ & $5(100 \%)$ \\
Median age $^{\mathrm{b}}$ (range) & $40.5(25-75)$ & $36(25-59)$ & $56(42-75)$ \\
$\begin{array}{l}\text { Mean hospital length of stay } \\
\text { (days, confidence interval) }\end{array}$ & $19( \pm 11.5)$ & $22( \pm 10.2)$ & $5( \pm 2.4)$ \\
$\begin{array}{l}\text { Evacuated from West Africa } \\
\text { Infected outside West Africa }\end{array}$ & $20(74 \%)$ & $16(80 \%)$ & $4(20 \%)$ \\
\hline
\end{tabular}

${ }^{a}$ Gender available for 25 patients

${ }^{\mathrm{b}}$ Age available for 22 patients 
followed by bleeding, as well as preterm labor and stillbirth if Ebola virus infection occurs later in pregnancy. Vertical transmission and subsequent neonatal mortality has been virtually uniform in the few documented live births by women with acute EVD [44]. A high Ebola viral load at time of admission is associated with more severe illness and mortality $[5,6,29,43,45-47]$, with other markers of organ dysfunction variably associated with outcomes $[6,8,29,48]$.

\section{Monitoring and care delivery}

The management of critically ill EVD patients in a resource-constrained setting has historically been restricted to variable monitoring of daily clinical signs and symptoms without access to continuous assessment [8]. The need for strict IPC practices and separation of patient care areas in West Africa significantly limited documentation and review of daily clinical records both inside and outside of high-risk patient care. As the case burden decreased and the ratio of healthcare personnel to patients increased, assessments were performed more systematically at some Ebola treatment facilities, with temperature, heart rate, blood pressure, respiratory rate, pulse oximetry, qualitative descriptions of urine, and gastrointestinal output, as well as fluid balance estimation.

Laboratory data other than Ebola RT-PCR results were essentially unavailable at Ebola treatment facilities in West Africa early in the outbreak [33, 49, 50]. Initially, there was very limited attention to diagnostics other than Ebola RT-PCR. The point-of-care systems for monitoring biochemistry and hematology parameters, such as the $\mathrm{i}^{-\mathrm{STAT}^{\circ}}$ or the Piccolo Xpress ${ }^{\circ}$, were inconsistently utilized inside Ebola treatment facilities [5, 6, 48], in part due to limited manufacturer-recommended temperature and humidity ranges. Over the course of the West African outbreak, with support from national and deployed international laboratories, basic biochemistry, blood counts, and coagulation profiles helped to characterize the course of illness, but remained inconsistently available and often with substantial delays in results reporting due to transport and processing time. Malaria rapid diagnostic tests, and less commonly RT-PCR, were available at most of the laboratories that supported Ebola treatment facilities in West Africa. However, testing for Lassa fever virus (endemic in EBOV-affected countries) or other causes of sepsis was not routine.

Bedside ultrasonography has not been widely deployed [51] but could help with assessing volume status, responsiveness to intravenous fluids [50], and assessment of challenging clinical signs such as abdominal distension [42]. Plain chest and abdomen radiography has been performed in European and North American settings [52] but has rarely been available to patients with Ebola in West Africa. Among patients treated in the USA and Europe, pulmonary edema has been reported in $44 \%$ and acute respiratory distress syndrome in another $22 \%$ [40].

\section{Discharge criteria and virus persistence during convalescence}

The World Health Organization (WHO) recommends considering discharge of patients from isolation on the basis of a negative blood Ebola virus RT-PCR result taken at least 3 days after the resolution of symptoms $[33,41]$. However, Ebola virus can persist in certain body fluids after it is undetectable in the blood and after clinical recovery from EVD [42, 53-56]. Viable Ebola virus has been isolated from urine, semen, cerebrospinal fluid, and vitreous humor many months after blood clearance [42, 56-61], suggesting that some activities (unprotected sex, invasive procedures, or penetrating eye trauma) confer a transmission risk even after symptoms and viremia resolve. It is therefore critical to counsel EVD survivors about the risks of Ebola virus persistence $[59,60]$ and appropriate precautions after discharge, including barrier protection during sexual intercourse [50] until semen has tested negative for Ebola virus twice, or for at least 6 months after EVD onset [62]. Health workers and others should continue to apply standard precautions, as with all patients, when evaluating EVD survivors in the convalescent period. Additional infection prevention and control practices, based upon an individual patient risk assessment, may be prudent for specific procedures in convalescence, even when there is no detectable EBOV in the blood (e.g., lumbar puncture or vitreous humor sampling) [63].

\section{Critical and supportive care interventions}

Providing supportive care to critically ill patients with EVD in resource-poor settings is challenging [64] due to limited infrastructure, lack of materials and trained healthcare personnel, and uncertainty regarding the translation of modern sepsis treatment strategies [65] and optimal intravenous fluid management protocols in the absence of advanced monitoring used in resourcerich settings [66]. Respiratory symptoms such as cough are not a prominent feature of EVD and tachypnea likely represents respiratory compensation of severe metabolic acidosis $[9,30,50]$. Translating fluid resuscitation protocols used in a resource-rich setting [42] to settings where supplemental oxygen therapy is not routinely available [49], in a disease with possible vascular leak syndrome [38], could result in increased morbidity [67] and warrants further investigation [68-70]. The use of antibiotics is common at Ebola treatment facilities [5, 6] before the diagnosis of EVD is confirmed in febrile patients and as empiric treatment of potential bacterial co-infection or gastrointestinal bacterial translocation in patients with confirmed EVD [9]. However, disruption of 
gastrointestinal flora due to broad-spectrum antibiotics could exacerbate diarrhea and fluid losses. Symptomatic treatment of severe diarrhea with loperamide was variably employed across Ebola treatment facilities. The risks and benefits of these practices warrant evaluation with observational studies and clinical trials [71].

Early and during the peak of the outbreak, clinical management was generally limited to supportive care focusing on aggressive oral and occasional intravenous volume resuscitation. As the case numbers decreased, advanced care became more common in some treatment facilities. Despite the limitations of working in PPE, feasibility and safety of central venous catheter placement was demonstrated at a UK military-supported treatment facility in Kerry Town, Sierra Leone [72]. Feasibility of transthoracic echocardiography was demonstrated at a military Ebola treatment facility in Conakry, Guinea [51]. By mid-December 2014, EMERGENCY, an Italian nongovernmental organization, established an Ebola critical care unit in Lakka and Goderich, Sierra Leone, the latter consisting of constant bedside nursing, continuous blood pressure, heart rate, respiratory rate monitoring, pulse oximetry, arterial and venous cannulation, nasogastric tube feeding, invasive ventilation, continuous renal replacement therapy, diagnostic biochemistry and hematology, ultrasonography, and plain radiography (Fig. 2). With waning case numbers, accurate evaluation of the impact of these interventions on patient outcomes has not been possible. Other sites, such as the GOAL-supported Mathaska Ebola Treatment Unit (ETU) and the Partners in Health-supported Maforki ETU in Sierra Leona also began using aspects of critical care procedures by February 2015, including nasogastric tube feeding, bedside ultrasound, as well as intraosseus cannulation for intravenous fluid resuscitation [73].

The historical philosophy of providing only oral fluids for EVD care has given way to the delivery of context-

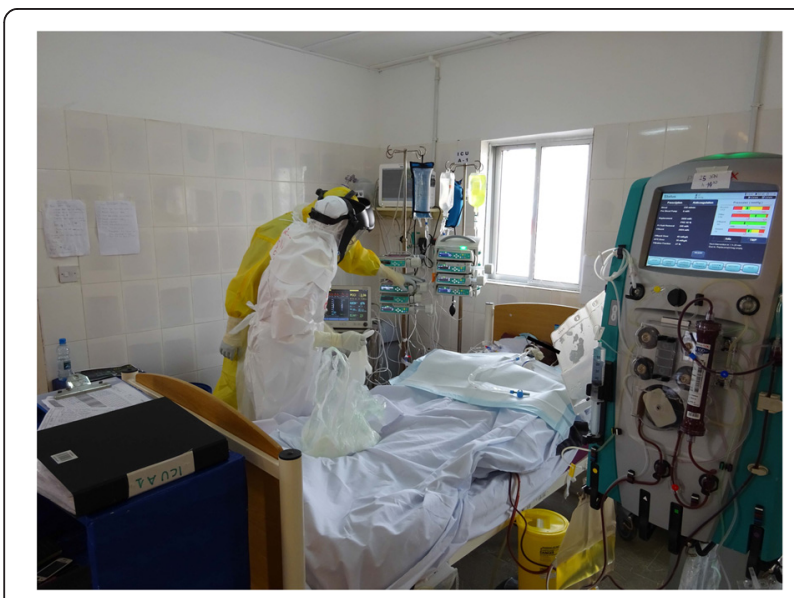

Fig. 2 Ebola treatment facility, Goderich, Sierra Leone-February 2015 appropriate critical care [38, 42, 74-79]. To date, 27 patients managed in nine countries outside of West Africa (Table 1) have been described, with a survival of $81.5 \%$ [40] (Table 2). Thirteen detailed accounts of EVD management in modern healthcare settings in the USA, Germany, Spain, and Switzerland provide insight into the course of the illness [38, 42, 76-82] (Table 3). These case reports confirm that intensive care monitoring in appropriately prepared centers is feasible. Noninvasive ventilation $[38,42]$, mechanical ventilation $[38,78,81]$, central venous catheter insertion for vasopressor support [38, 42, 78, 79, 82], and renal replacement therapy $[38,78,81,82]$ can be provided effectively and safely (Table 3, Figs. 3 and 4) [83].

\section{Establishing supportive and critical care services in highly resourced settings}

While it may be advisable to concentrate or regionalize care for patients with EVD in specific hospitals, any health centre should be prepared to safely take a focused and relevant history from a patient with an infectious syndrome, and to mobilize the appropriate local and regional response. Many hospitals, even if not EVD referral centers, may be asked to care for patients until initial (and possibly subsequent) blood Ebola RT-PCR results are known. Therefore, it is essential that hospital staff are well trained and familiar with recommended IPC practices (and for EVD, standard and contact IPC precautions in particular). It is ideal to have an on-call inter-professional team who have undergone training in Ebola-specific IPC training.

While practiced IPC protocols are important to keep health workers safe, a very common clinical pitfall is to equate IPC practices with care. While Ebola-specific standardized IPC protocols are absolutely necessary, there will be situations requiring patient-specific IPC risk-assessments-most commonly involving patients at the beginning of, or in the convalescent phase of, their illness with minimal symptoms and no vomiting or diarrhoea (i.e., with very low risk of transmission). It is also important to remember that most patients suspected with EVD will not have EVD, but will have illness in need of prompt treatment-commonly malaria-that may require empiric treatment while awaiting diagnostic testing [84, 85]. Barriers to providing the standard of care to patients suspected of EVD will repeatedly arise: "We don't have the capacity to do that... that is not part of our protocol." Do not accept this when it negatively influences patient care. Instead, ask collectively "How can we safely solve this challenge, now, for the benefit of this patient?"

For hospitals and intensive care units (ICUs) that will provide definitive care for patients with EVD, there are many Ebola-specific considerations well beyond the scope of this review; however, a number deserve mention. 
Table 3 Clinical management summary of 13 Ebola virus disease patients treated outside West Africa

\begin{tabular}{|c|c|c|c|c|c|c|c|c|c|c|c|c|c|}
\hline Reference & [76] & [76] & {$[42]$} & {$[28,79,137]$} & {$[78,79,82]$} & {$[81,82]$} & [38] & {$[25,77]$} & {$[28,99]$} & {$[81]$} & [81] & {$[82]$} & {$[37]$} \\
\hline \multicolumn{14}{|l|}{ Demographics } \\
\hline Gender & M & $\mathrm{F}$ & M & M & M & M & M & $\mathrm{F}$ & M & $\mathrm{F}$ & $\mathrm{F}$ & M & M \\
\hline Age (years) & 33 & 59 & 36 & 51 & 43 & 42 & 38 & 44 & 33 & 26 & 29 & 44 & 43 \\
\hline $\begin{array}{l}\text { Country of } \\
\text { infection }\end{array}$ & Liberia & Liberia & Sierra Leone & Liberia & Sierra Leone & Liberia & Sierra Leone & Spain & Liberia & USA & USA & Sierra Leone & Sierra Leone \\
\hline $\begin{array}{l}\text { Country } \\
\text { providing care }\end{array}$ & USA & USA & Germany & USA & USA & USA & Germany & Spain & USA & USA & USA & USA & Switzerland \\
\hline \multicolumn{14}{|l|}{ Hospital admission } \\
\hline Admission date & 2 Aug 2014 & 5 Aug 2014 & 27 Aug 2014 & 5 Sep 2014 & 9 Sep 2014 & 30 Sep 2014 & 3 Oct 2014 & 6 Oct 2014 & 6 Oct 2014 & 11 Oct 2014 & 14 Oct 2014 & 15 Nov 2014 & 21 Nov 2014 \\
\hline $\begin{array}{l}\text { Days from } \\
\text { diagnosis to } \\
\text { evacuation }\end{array}$ & 7 & 10 & 4 & 7 & 2 & N/A & 5 & 0 & 5 & N/A & N/A & 6 & 4 \\
\hline Hospital LOS & 19 & 14 & 30 & 20 & 41 & 8 & 47 & 30 & 16 & 13 & 14 & 3 & 15 \\
\hline Vital status & Survived & Survived & Survived & Survived & Survived & Died & Survived & Survived & Survived & Survived & Survived & Died & Survived \\
\hline \multicolumn{14}{|c|}{ Critical care therapies } \\
\hline Central line & $\mathrm{N}$ & N & Y & Y & Y & Y & Y & $\mathrm{N}$ & Y & Y & $N$ & Y & Y \\
\hline Vasopressors & N & N & $N$ & N & Y & Y & Y & N & $N$ & N & N & Y & N \\
\hline Oxygen & Y & Y & Y & Y & Y & Y & Y & Y & N & N & N & Y & $\mathrm{N}$ \\
\hline NIV (d, days) & $\mathrm{N}$ & N & $Y(8 d)$ & $\mathrm{N}$ & $\mathrm{N}$ & $N$ & $Y(1 d)$ & $N$ & N & N & N & $\mathrm{N}$ & $\mathrm{N}$ \\
\hline MV (d, days) & N & N & N & N & $Y(17 d)$ & $Y(5 d)$ & $Y(13 d)$ & N & N & N & N & $Y(3 d)$ & N \\
\hline CRRT (d, days) & $\mathrm{N}$ & $\mathrm{N}$ & N & $\mathrm{N}$ & $Y(24 d)$ & $Y(5 d)$ & $Y(18 d)$ & $\mathrm{N}$ & N & N & N & $Y(3 d)$ & $\mathrm{N}$ \\
\hline IHD (d, days) & $\mathrm{N}$ & $\mathrm{N}$ & $\mathrm{N}$ & $\mathrm{N}$ & $\mathrm{N}$ & N & $Y(10 d)$ & N & N & N & $N$ & $\mathrm{~N}$ & $\mathrm{~N}$ \\
\hline \multicolumn{14}{|c|}{ Experimental therapies } \\
\hline $\begin{array}{l}\text { Convalescent } \\
\text { plasma }\end{array}$ & Y & N & N & Y & Y & N & N & Y & Y & Y & Y & Y & N \\
\hline ZMapp/ZMab & Y & Y & N & N & N & N & N & Y & $N$ & Y & N & Y & Y \\
\hline Brincidofovir & N & N & N & $N$ & $\mathrm{~N}$ & Y & N & N & Y & Y & Y & N & N \\
\hline Favipiravir & N & N & Y & N & $\mathrm{N}$ & N & Y & Y & N & N & N & N & Y \\
\hline TKM & N & N & Y & Y & Y & N & N & N & N & Y & N & N & N \\
\hline Other & N/A & N/A & N/A & N/A & N/A & N/A & $\begin{array}{l}\text { Amiodarone, } \\
\text { FX06 }\end{array}$ & N/A & N/A & N/A & N/A & N/A & N/A \\
\hline
\end{tabular}

CRRT continuous renal replacement therapy; $F$ female, IHD intermittent hemodialysis, LOS length of stay, $M$ male, $M V$ invasive mechanical ventilation, N/A not available, NIV non-invasive ventilation, TKM TKM-Ebola, small interfering ribonucleic acids (siRNA) produced by Tekmira 


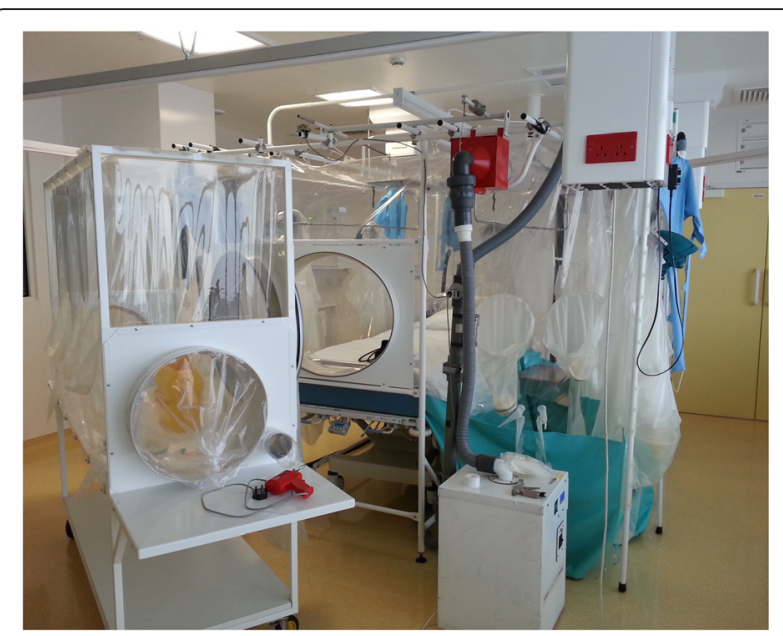

Fig. 3 Ebola treatment facility, Royal Free Hospital, London, UK-September 2014

Hospitals and ICUs will generally need to mould EVD planning to the local environment, and seek out the experience, guidance, protocols, and training from those who have substantial clinical and operational experience (Figs. 3, 4) [64, 86].

Second, the physical environment of a proposed Ebola treatment unit is a critical component of care. Ideally, there should be a large available physical space, sufficient for multiple isolation rooms, with very generously sized antechamber areas for donning and doffing, and a shared area from where clinical observation can occur (Fig. 4). There should be sufficient adjoining space to house dedicated diagnostic (e.g., portable radiograph and ultrasound machines, potentially point-of-care laboratory devices) and therapeutic (intravenous pumps, mechanical ventilator and circuits, dialysis machine and supplies) equipment. There should be ample nearby space to house packaged soiled PPE and medical waste that allows pick-up and proper disposal.

Third is the necessity for sufficiently numerous and trained inter-professional team of clinical (nurses, physicians, respiratory therapists, others) and patient support staff (coordinators, monitors, cleaners, patient transportation services, diagnostic and laboratory staff, and so forth), who are well practiced in the institutional Ebola care plan and their specific roles. Whether this team is led by infectious disease or critical care specialists, or both, is likely less important than establishing an interdisciplinary model of continuity care throughout the hospital stay, oftentimes in a single geographic location that is institutionally appropriate.

Fourth, while EVD is accompanied by an increasingly well-characterized clinical gastrointestinal syndrome

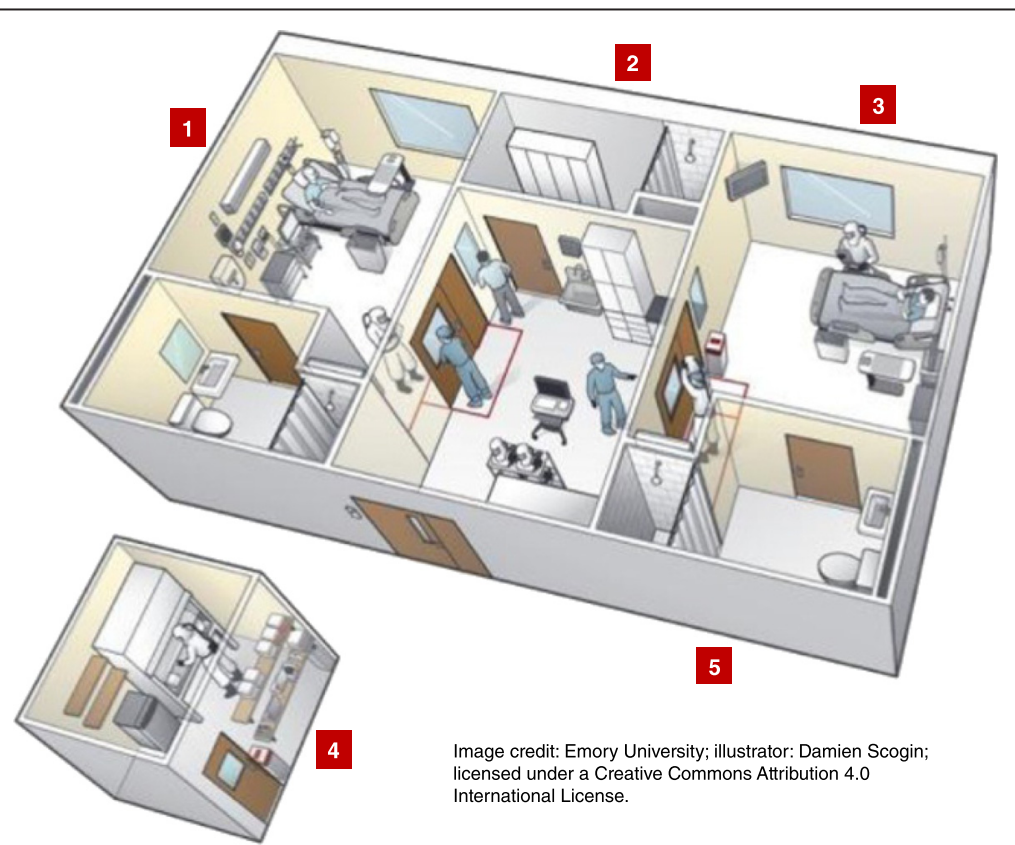

Fig. 4 Emory University Hospital special isolation unit. (1) The private patient rooms resemble intensive acre unit rooms, with adjustable beds, intravenous drips, and monitors. Every procedure a patient could need, from mechanical ventilation to hemodialysis, can be performed in the unit. (2) Medical staff who are providing direct patient care use a locker room to change into full-body protective suits and masks, which shield them from blood and bodily fluids. (3) Family members are able to speak with patients through glass windows in the unit; patients have access to phones and laptop computers. (4) A dedicated lab was built specifically for the use with the isolation unit that has the capacity to perform blood counts, routine chemistries, blood gas measurements, urinalysis, and tests for a variety of infectious agents. (5) All liquid waste is disinfected and flushed, and disposable waste is autoclaved and incinerated. At the peak of an Ebola patient's illness, up to 40 bags a day of medical waste were produced 
leading to fluid, electrolyte, and acid-base imbalance with multisystem organ dysfunction, there are no Ebolaspecific therapies yet to be proven effective. However, intensive care medicine comprises experiential and evidence-based organ-supportive care, which should guide the care of patients with EVD-attention to fluid, electrolyte and acid-base balance, initiation of empiric and specific anti-infective therapy, and support for renal injury and respiratory failure as occurs for other potentially self-limited and survivable illnesses. Among patients with EVD treated in the USA and Europe, $41 \%$ were deemed to have critical illness with $70 \%$ receiving supplemental oxygen, $22 \%$ with acute respiratory distress syndrome, $26 \%$ invasive mechanical ventilation, $30 \%$ intravenous vasoactive medications, and $19 \%$ requiring dialysis [40].

For the most severely ill patients, clinical judgment is always necessary to balance risks and benefits of certain resuscitation strategies, including the initiation of cardiopulmonary resuscitation (CPR) [28, 87]. While there is a lack of clinical experience with CPR in EVD patients, it may be a reasonable consideration while correcting reversible abnormalities (i.e., hypoxia, severe electrolyte disturbance, arrhythmias) in settings where the option for advanced life-support exists. The decision to provide CPR should be guided by its medical indication and utility in that context, the ability to provide effective $\mathrm{CPR}$, and the safety of those providing care including safe donning and doffing of PPE, in addition to patient preferences $[88,89]$.

Fifth, as with all critical illness, medical technical care is only one dimension of our support for patients and their families. Patients with EVD and their families require mechanisms to stay in audio and visual contact throughout the illness-ideally visual contact through transparent barriers or at safe distance, or direct contact with supervised donning and doffing of PPE-in addition to substantial psychosocial support during and after EVD.

\section{Ebola-specific pharmacological prevention and therapeutics}

Current EVD treatment focuses on supportive care [70] as there are no specific treatment options yet to be proven effective [70, 90, 91]. A number of Ebola-specific treatment strategies have undergone preliminary clinical trial investigation, including convalescent plasma, Favipiravir, Brincidofovir and TMK-130803 [92-97]. Transfusion of convalescent whole blood or plasma donated by EVD survivors has been used in this and prior EVD outbreaks [98] in an uncontrolled or compassionate-use basis $[25,79,81,99]$, and in animal models [100, 101]. One of three clinical trials of convalescent plasma therapy [94] has been completed and reported [102]. In this nonrandomized comparison to historical controls, transfusion of up to $500 \mathrm{ml}$ convalescent plasma with unknown levels of neutralizing antibodies in 84 patients with confirmed EVD was not associated with a significant improvement in survival. While there were no serious adverse reactions in this trial, transfusion-related acute lung injury was described during convalescent plasma therapy in Spain [25]. Favipiravir (Toyama, Japan) [103], a pre-existing influenza virus inhibitor, has been administered for compassionate use outside West Africa [37, 38, 42]. In a multicenter, nonrandomized clinical trial in Guinea [104], 111 patients receiving Favipiravir had similar survival to that based upon historical control patients. The trial authors suggested that Favipiravir should be further studied in patients with medium to high viremia, but not in those with very high viremia [105]. Brincidofovir (Chimerix, USA), a nucleotide ana$\log$ that inhibits RNA-polymerase with in vitro activity against Ebola [106], was administered to a small number of EVD patients for uncontrolled compassionate use $[42,79,81,99]$ and was tested in a phase 2 clinical trial in Liberia [95] that was stopped after the manufacturer withdrew study support [107]. TKM-130803 is a formulation of lipid-nanoparticle-encapsulated small interfering ribonucleic acids (siRNA) targeting two proteins involved in Ebola virus transcription and replication (Tekmira, USA, Canada). It was used in nonhuman primate Ebola virus infection as a postexposure treatment strategy [108] and in patients medically evacuated from West Africa in uncontrolled compassionate use $[79,81]$. However, a phase 2 clinical trial (RAPIDE-TKM) in Sierra Leone [96] was halted according to pre-established stopping rules [109].

ZMapp, a monoclonal antibody cocktail (Leafbio, USA) [110], has been used under the emergency investigational new drug approvals from the Food and Drug Administration in patients treated in the USA, West Africa, and Western Europe [40, 76, 111]. ZMapp treatment of rhesus macaques resulted in $100 \%$ survival even when started 5 days after lethal EBOV infection [110]. In the only randomized controlled trial of an investigational therapeutic for EVD, ZMapp plus standard of care was compared to standard of care alone for EVD patients in four countries, including the three most impacted West African countries. Due to the decline in EVD cases, this unblinded ZMapp randomized controlled trial only enrolled 72 of the prespecified target goal of 200 EVD patients; data were analyzed for 71 EVD patients, and mortality in the ZMapp treatment group was $22 \%$ versus $37 \%$ in the untreated group, but this difference was not statistically significant $[112,113]$.

The open-label, uncontrolled, and selected administration of other agents such as amiodarone [114], HMGCoA reductase inhibitors, and angiotensin II receptor antagonists [115], and therapies to counteract vascular 
leak (FX06) [38] preclude any conclusions. In an observational study examining temporal trends in mortality among patients with EVD in one ETU in Guinea, 125 of $194(64.4 \%)$ patients receiving artemether-lumefantrine for malaria prophylaxis died as compared with 36 of 71 patients receiving artesunate-amodiaquine (50.7 \%). In adjusted analyses, the risk ratio was 0.69 (95\% confidence interval, 0.54 to 0.89 ), with a stronger effect observed among patients without malaria [116]. These findings have not been confirmed in a randomized clinical trial.

Two vaccine candidates demonstrated efficacy in nonhuman primates [92, 117, 118]. A recombinant, replication-competent vesicular stomatitis virus-based vaccine expressing a surface glycoprotein of Zaire ebolavirus rVSVAG-EBOV-GP (rVSV) [118, 119] was evaluated in an open-label, ring vaccination trial involving 7651 people in 90 clusters, randomized to immediate or delayed (21 days) administration. The vaccine was well tolerated and in the immediate vaccination group there were no new EVD cases while in the delayed vaccination group there were 16 EVD cases [120]. Another candidate vaccine, cAd3-EBOV (cAd3) [117] remains under investigation $[92,121]$. Other vaccine candidates are also under development and evaluation $[122,123]$.

\section{Post-exposure Prophylaxis}

Several healthcare personnel received post-exposure prophylaxis with different interventions, including a candidate Ebola vaccine, following potential high-risk exposures to Ebola virus; although Ebola virus disease did not occur in these individuals, no conclusions can be made about the effectiveness of these uncontrolled interventions [124-126].

\section{Ethical challenges in caring for patients with Ebola virus disease}

Each of the commonly applied four principles of medical bioethics faces numerous threats in treating patients with EVD [87]. A symptomatic patient's autonomy to not seek treatment (and not be isolated) is weighed against the threat of disease transmission by staying in the community. The injustice of treatment variability, across regions and over time, places patients at differential risk of death. In acting beneficently, healthcare workers inherently place themselves at some risk. A natural response is to balance that risk with the duty to help. This frequently conspires against greater numbers of health workers responding to an Ebola outbreak. The duty to nonmaleficence, doing no harm, is a daily conundrum, through potential delays in routine diagnostic work-up for common illnesses because of a lack of diagnostic testing, or, in resource-constrained environments, inadequate space to separate potentially infectious suspect patients along a gradient of risk.

\section{Post-Ebola syndrome}

With over 11,000 EVD survivors, there is increased recognition of a post-Ebola syndrome in the convalescent period, characterized by mental health and cognitive sequelae, chronic headaches, insomnia, arthralgias, auditory disturbances, and ocular effects including sightthreatening uveitis [127-132]. It is uncertain whether these manifestations are due to direct viral cytopathic effect in immune-privileged compartments or postinfectious immune-mediated inflammation [133-135].

\section{Research directions}

Although this EVD outbreak narrowed some knowledge gaps, pathophysiology and the immunological response to acute infection and convalescence is still minimally characterized. Access to rapid point-of-care EVD diagnostic capacity to differentiate between other common febrile illnesses [136] is critical because the early presentation of EVD has a broad differential diagnosis [5, 7, 34]. Laboratory testing to identify prognostic indicators could help guide clinical care. Evaluation of specific antiviral therapies is critical as is evaluation of commonly used treatments for which there is still very limited evidence (e.g., empiric antibiotics, anti-diarrheal agents, and fluid replacement composition and volume). The safety and functionality of PPE must be improved. Standardized, easy-to-use clinical charting and human resources for data entry should be made available to support cohort studies and clinical trials. While it seems intuitive that provision of advanced supportive and critical care improves patient outcomes, operationalizing and evaluating increased levels of care to resource-challenged environments is needed. Prepared research protocols that can be rapidly adapted to countryspecific settings and quickly implemented could reduce research delays in future outbreaks. Following patients who survive EVD is important to better characterize immune correlates of virus clearance and host genetic factors that contribute to survival, and to better address morbidity of the post-Ebola syndrome.

\section{Conclusions}

The provision of advanced supportive and critical care for EVD patients, while challenging, is possible in both West African and more developed healthcare settings. Creating and evaluating context-appropriate intensive care capacity is a knowledge translation priority. The experience of this outbreak emphasizes that, in addition to evaluating specific medical treatments, improving the global capacity to provide supportive critical care to patients with severe illness may be associated with the greatest opportunity to improve patient outcomes. 


\section{Additional file}

Additional file 1: Weblink references for Tables 1-3. (DOCX $124 \mathrm{~kb}$ )

\section{Abbreviations}

CPR, cardiopulmonary resuscitation; EBOV, Ebola virus; ETU, Ebola Treatment Unit; EVD, Ebola virus disease; ICU, intensive care unit; IL, interleukin; IPC, infection prevention and control; PPE, personal protective equipment; $R T-P C R$, real-time reverse transcription polymerase chain reaction

\section{Authors' contributions}

RAF, AL, WAFII, TEF, and TMU conceived of the study, participated in its design and coordination, collected data, performed the statistical analysis and drafted the manuscript. NKJA, GP, FL, TMU, CC, STJ, LR, AV, JH, SM, MF, IC, EIB, MCL, JSS, DBM, DGB, NS, AC, TOD, SM, MJ, SD, and GMLIII participated in the design of the study, helped in data collection and helped to revise the manuscript. All authors read and approved the final manuscript.

\section{Competing interests}

The authors declare that they have no competing interests.

\section{Disclaimer}

The findings and conclusions in this report are those of the authors and do not necessarily represent the official position of the Centers for Disease Control and Prevention.

\section{Author details}

'Interdepartmental Division of Critical Care, University of Toronto, Toronto, ON, Canada. ${ }^{2}$ Department of Medicine, University of North Carolina, Chapel Hill, NC, USA. ${ }^{3}$ Centers for Disease Control and Prevention, Atlanta, Georgia, USA. ${ }^{4}$ Defence Medical Services, Whittington Barracks, Lichfield, UK. ${ }^{5}$ Liverpool School of Tropical Medicine, Liverpool, Merseyside, UK. ${ }^{6}$ Department of Critical Care Medicine, Sunnybrook Health Sciences Centre, Toronto, ON, Canada. ${ }^{7}$ Emergency NGO, Milan, Italy. ${ }^{8}$ Department of Medicine, Université de Sherbrooke, Sherbrooke, Quebec, Canada. ${ }^{9}$ Polyclinique Bordeaux Nord Aquitaine, Bordeaux, France. ${ }^{10}$ Department of Medicine, University of Washington, Seattle, Washington, USA. ${ }^{11}$ Department of Medicine, University of Maryland, Baltimore, MD, USA. ${ }^{12}$ Centre de recherche de l'institut Universitaire de Cardiologie et de Pneumologie de Québec, Quebec City, Quebec, Canada. ${ }^{13}$ Division of Infectious Diseases, University of British Columbia, Vancouver, BC, Canada. ${ }^{14}$ Department of Paediatrics, University of British Columbia, Vancouver, BC, Canada. ${ }^{15}$ Infectious Diseases Institute, College of Health Sciences, Makerere University, Kampala, Uganda. ${ }^{16}$ Department of Infectious and Parasitic Diseases, Donka Hospital, Conakry, Guinea. ${ }^{17}$ Department of Pediatrics, School of Medicine and School of Public Health and Tropical Medicine, Tulane University, New Orleans, LA, USA. ${ }^{18}$ Department of Preventive Medicine and Biometrics, Uniformed Services University, Bethesda, MD, USA.

${ }^{19}$ Department of Pandemic and Epidemic Diseases, World Health Organization, Geneva, Switzerland. ${ }^{20}$ Division of Infectious Diseases, Sunnybrook Health Sciences Centre, Toronto, ON, Canada. ${ }^{21}$ Department of Clinical Sciences, Liverpool School of Tropical Medicine, Liverpool, UK. ${ }^{22}$ Department of Medicine, University of Toronto, Toronto, ON, Canada. ${ }^{23}$ Department of Infection, Royal Free London NHS Foundation Trust, London, UK. ${ }^{24}$ Acute Medicine and Intensive Care, Derriford Hospital, Plymouth, UK. ${ }^{25}$ Department of Infectious Diseases, Emory University Hospital, Atlanta, Georgia, USA.

\section{Received: 3 March 2016 Accepted: 26 April 2016}

\section{Published online: 29 July 2016}

\section{References}

1. Baize S, Pannetier D, Oestereich L, et al. Emergence of Zaire Ebola virus disease in Guinea. N Engl J Med. 2014;371(15):1418-25.

2. Bres P. The epidemic of Ebola haemorrhagic fever in Sudan and Zaire, 1976: introductory note. Bull World Health Organ. 1978;56(2):245.

3. CDC. Outbreaks Chronology: Ebola Virus Disease. http://www.cdc.gov/vhf/ ebola/outbreaks/history/chronology.html. Accessed 7 Sep 2015.

4. Feldmann H, Geisbert TW. Ebola haemorrhagic fever. Lancet. 2011;377(9768): 849-62.
5. Bah El, Lamah MC, Fletcher T, et al. Clinical presentation of patients with Ebola virus disease in Conakry. Guinea N Engl J Med. 2015;372(1):40-7.

6. Schieffelin JS, Shaffer JG, Goba A, et al. Clinical illness and outcomes in patients with Ebola in Sierra Leone. N Engl J Med. 2014;371(22):2092-100.

7. Fauci AS. Ebola-underscoring the global disparities in health care resources. N Engl J Med. 2014;371(12):1084-6.

8. Kortepeter MG, Bausch DG, Bray M. Basic clinical and laboratory features of filoviral hemorrhagic fever. J Infect Dis. 2011;204 Suppl 3:S810-6.

9. Bwaka MA, Bonnet MJ, Calain P, et al. Ebola hemorrhagic fever in Kikwit, Democratic Republic of the Congo: clinical observations in 103 patients. J Infect Dis. 1999;179 Suppl 1:S1-7.

10. Peters CJ, LeDuc JW. An introduction to Ebola: the virus and the disease. J Infect Dis. 1999;179 Suppl 1:ix-xvi.

11. WHO. Ebola haemorrhagic fever in Zaire, 1976. Bull World Health Organ. 1978:56(2):271-93

12. WHO. Ebola haemorrhagic fever in Sudan, 1976 Report of a WHO/ International Study Team. Bull World Health Organ. 1978;56(2):247-70.

13. Gire SK, Goba A, Andersen KG, et al. Genomic surveillance elucidates Ebola virus origin and transmission during the 2014 outbreak. Science. 2014;345(6202):1369-72

14. CDC. 2014 Ebola Outbreak in West Africa - Reported Cases Graphs. http://www.cdc.gov/vhf/ebola/outbreaks/2014-west-africa/cumulative-casesgraphs.html. Accessed 7 Sep 2015.

15. WHO. Ebola Situation Reports. http://apps.who.int/ebola/ebola-situationreports, Accessed 20 May 2016.

16. Team WHOER. Ebola virus disease in West Africa - the first 9 months of the epidemic and forward projections. N Engl J Med. 2014;371(16):1481-95.

17. Victory KR, Coronado F, Ifono SO, et al. Ebola transmission linked to a single traditional funeral ceremony-Kissidougou, Guinea, December, 2014January 2015. MMWR Morb Mortal Wkly Rep. 2015;64(14):386-8.

18. WHO. Interim infection prevention and control guidance for care of patients with suspected or confirmed filovirus haemorrhagic fever in health-care settings, with focus on Ebola. Geneva, Switzerland: WHO; 2014.

19. Johnson $E_{\text {, Jax }} \mathrm{N}$, White J, et al. Lethal experimental infections of rhesus monkeys by aerosolized Ebola virus. Int J Exp Pathol. 1995;76(4):227-36.

20. Jaax N, Jahrling P, Geisbert T, et al. Transmission of Ebola virus (Zaire strain) to uninfected control monkeys in a biocontainment laboratory. Lancet. 1995;346(8991-8992):1669-71

21. Brearley MB, Heaney MF, Norton IN. Physiological responses of medical team members to a simulated emergency in tropical field conditions. Prehosp Disaster Med. 2013;28(2):139-44.

22. WHO. Health worker Ebola infections in Guinea, Liberia and Sierra Leone. Geneva, Switzerland: WHO; 2015

23. Suwantarat $N$, Apisarnthanarak A. Risks to healthcare workers with emerging diseases: lessons from MERS-CoV, Ebola, SARS, and avian flu. Curr Opin Infect Dis. 2015;28(4):349-61.

24. Lopaz MA, Amela C, Ordobas M, et al. First secondary case of Ebola outside Africa: epidemiological characteristics and contact monitoring, Spain, September to November 2014. Euro Surveill. 2015;20(1).

25. Mora-Rillo M, Arsuaga M, Ramirez-Olivencia G, et al. Acute respiratory distress syndrome after convalescent plasma use: treatment of a patient with Ebola virus disease contracted in Madrid. Spain Lancet Respir Med. 2015;3(7):554-62.

26. Chevalier MS, Chung W, Smith J, et al. Ebola virus disease cluster in the United States-Dallas County, Texas, 2014. MMWR Morb Mortal Wkly Rep. 2014;63(46):1087-8.

27. Tartari $E$, Allegranzi B, Ang B, et al. Preparedness of institutions around the world for managing patients with Ebola virus disease: an infection control readiness checklist. Antimicrob Resist Infect Control. 2015;4:22.

28. Johnson DW, Sullivan JN, Piquette CA, et al. Lessons learned: critical care management of patients with Ebola in the United States. Crit Care Med. 2015:43(6):1157-64

29. McElroy AK, Erickson BR, Flietstra TD, et al. Ebola hemorrhagic fever: novel biomarker correlates of clinical outcome. J Infect Dis. 2014;210(4):558-66.

30. Fletcher TE, Fowler RA, Beeching NJ. Understanding organ dysfunction in Ebola virus disease. Intensive Care Med. 2014:40(12):1936-9.

31. WHO. Case definition recommendations for Ebola or Marburg Virus Diseases. 2014. http://www.who.int/csr/resources/publications/ebola/ebolacase-definition-contact-en.pdf, Accessed 7 Sep 2015.

32. Martin $\mathrm{P}$, Laupland KB, Frost EH, et al. Laboratory diagnosis of Ebola virus disease. Intensive Care Med. 2015;41(5):895-8.

33. WHO. Clinical management of patients with viral haemorrhagic fever: a pocket guide for the front-line health worker. Geneva, Switzerland: WHO; 2014. 
34. Broadhurst MJ, Kelly JD, Miller A, et al. ReEBOV Antigen Rapid Test kit for point-of-care and laboratory-based testing for Ebola virus disease: a field validation study. Lancet. 2015;386(9996):867-74.

35. Emond RT, Evans B, Bowen ET, et al. A case of Ebola virus infection. Br Med J. 1977;2(6086):541-4.

36. Nkoghe D, Leroy EM, Toung-Mve M, et al. Cutaneous manifestations of filovirus infections. Int J Dermatol. 2012;51(9):1037-43.

37. Schibler $M$, Vetter $P$, Cherpillod $P$, et al. Clinical features and viral kinetics in a rapidly cured patient with Ebola virus disease: a case report. Lancet Infect Dis. 2015;15(9):1034-40.

38. Wolf T, Kann G, Becker S, et al. Severe Ebola virus disease with vascular leakage and multiorgan failure: treatment of a patient in intensive care. Lancet. 2015;385(9976):1428-35.

39. Khan AS, Tshioko FK, Heymann DL, et al. The reemergence of Ebola hemorrhagic fever, Democratic Republic of the Congo, 1995. Commission de Lutte contre les Epidemies a Kikwit. J Infect Dis. 1999;179 Suppl 1:S76-86.

40. Uyeki TM, Mehta AK, Davey RT Jr, Liddell AM, Wolf T, Vetter P, Schmiedel S, Grünewald T, Jacobs M, Arribas JR, Evans L, Hewlett AL, Brantsaeter AB, Ippolito G, Rapp C, Hoepelman Al, Gutman J; Working Group of the U.S.European Clinical Network on Clinical Management of Ebola Virus Disease Patients in the U.S. and Europe. Clinical Management of Ebola Virus Disease in the United States and Europe. N Engl J Med. 2016;18;374(7):636-46.

41. Chertow DS, Kleine C, Edwards JK, et al. Ebola virus disease in West Africa_clinical manifestations and management. N Engl J Med. 2014; 371(22):2054-7.

42. Kreuels B, Wichmann D, Emmerich $P$, et al. A case of severe Ebola virus infection complicated by gram-negative septicemia. N Engl J Med. 2014 371(25):2394-401.

43. Fitzpatrick G, Vogt F, Moi Gbabai OB, et al. The contribution of Ebola viral load at admission and other patient characteristics to mortality in a Medecins Sans Frontieres Ebola Case Management Centre, Kailahun, Sierra Leone, June-October 2014. J Infect Dis. 2015;212(11):1752-8.

44. Mupapa K, Mukundu W, Bwaka MA, et al. Ebola hemorrhagic fever and pregnancy. J Infect Dis. 1999;179 Suppl 1:S11-12.

45. Towner JS, Rollin PE, Bausch DG, et al. Rapid diagnosis of Ebola hemorrhagic fever by reverse transcription-PCR in an outbreak setting and assessment of patient viral load as a predictor of outcome. J Virol. 2004;78(8):4330-41.

46. Faye $\mathrm{O}$, Andronico $\mathrm{A}$, Faye $\mathrm{O}$, et al. Use of viremia to evaluate the baseline case fatality ratio of Ebola virus disease and inform treatment studies: a retrospective cohort study. PLoS Med. 2015;12(12):e1001908.

47. Lanini S, Portella G, Vairo F, et al. Blood kinetics of Ebola virus in survivors and nonsurvivors. J Clin Invest. 2015;125(12):4692-8.

48. Rollin PE, Bausch DG, Sanchez A. Blood chemistry measurements and Ddimer levels associated with fatal and nonfatal outcomes in humans infected with Sudan Ebola virus. J Infect Dis. 2007;196 Suppl 2:S364-371.

49. Fowler RA, Fletcher T. Fischer 2nd WA, et al. Caring for critically ill patients with Ebola virus disease. Perspectives from West Africa. Am J Respir Crit Care Med. 2014;190(7):733-7.

50. West TE. von Saint Andre-von Arnim A. Clinical presentation and management of severe Ebola virus disease. Ann Am Thorac Soc. 2014;11(9):1341-50.

51. Cellarier GR, Bordes J, Karkowski L, et al. Safety, feasibility, and interest of transthoracic echocardiography in a deployed French military Ebola virus disease treatment center in Guinea. Intensive Care Med. 2015;41(8):1491-2.

52. Auffermann WF, Kraft CS, Vanairsdale $S$, et al. Radiographic imaging for patients with contagious infectious diseases: how to acquire chest radiographs of patients infected with the Ebola virus. AJR Am J Roentgenol. 2015;204(1):44-8.

53. Bausch DG, Towner JS, Dowell SF, et al. Assessment of the risk of Ebola virus transmission from bodily fluids and fomites. J Infect Dis. 2007;196 Suppl 2:S142-7.

54. Formenty $\mathrm{P}$, Leroy EM, Epelboin A, et al. Detection of Ebola virus in oral fluid specimens during outbreaks of Ebola virus hemorrhagic fever in the Republic of Congo. Clin Infect Dis. 2006;42(11):1521-6.

55. Zaki SR, Shieh WJ, Greer PW, et al. A novel immunohistochemical assay for the detection of Ebola virus in skin: implications for diagnosis, spread, and surveillance of Ebola hemorrhagic fever. Commission de Lutte contre les Epidemies a Kikwit. J Infect Dis. 1999;179 Suppl 1:S36-47.

56. Rowe AK, Bertolli J, Khan AS, et al. Clinical, virologic, and immunologic followup of convalescent Ebola hemorrhagic fever patients and their household contacts, Kikwit, Democratic Republic of the Congo. Commission de Lutte contre les Epidemies a Kikwit. J Infect Dis. 1999;179 Suppl 1:S28-35.
57. Rodriguez LL, De Roo A, Guimard Y, et al. Persistence and genetic stability of Ebola virus during the outbreak in Kikwit, Democratic Republic of the Congo, 1995. J Infect Dis. 1999;179 Suppl 1:S170-6.

58. Varkey JB, Shantha JG, Crozier I, et al. Persistence of Ebola virus in ocular fluid during convalescence. N Engl J Med. 2015;372(25):2423-7.

59. Deen GF, Knust B, Broutet $N$, et al. Ebola RNA persistence in semen of Ebola virus disease survivors_-preliminary report. N Engl J Med. 2015. doi:10.1056/ NEJMoa1511410, http://www.nejm.org/doi/pdf/10.1056/NEJMoa1511410.

60. Mate SE, Kugelman JR, Nyenswah TG, et al. Molecular evidence of sexual transmission of Ebola virus. N Engl J Med. 2015;373(25):2448-54.

61. Jacobs M, Rodger A, Bell DJ, Bhagani S, Cropley I, Filipe A, Gifford RJ, Hopkins S, Hughes J, Jabeen F, Johannessen I, Karageorgopoulos D, Lackenby A, Lester R, Liu RS, MacConnachie A, Mahungu T, Martin D, Marshall N, Mepham S, Orton R, Palmarini M, Patel M, Perry C, Peters SE, Porter D, Ritchie D, Ritchie ND, Seaton RA, Sreenu VB, Templeton K, Warren S, Wilkie GS, Zambon M, Gopal R, Thomson EC. Late Ebola virus relapse causing meningoencephalitis: a case report. Lancet. 2016 May 18. pii: S0140-6736(16)30386-5. doi:10.1016/S01406736(16)30386-5. [Epub ahead of print].

62. WHO. Interim advice on the sexual transmission of the Ebola virus disease. Sexual and reproductive health. http://www.who.int/reproductivehealth/ topics/rtis/ebola-virus-semen/en. Accessed 22 Sep 2015.

63. CDC. Interim Guidance for Management of Survivors of Ebola Virus Disease in U.S Healthcare Settings. 2016. http:/www.cdc.gov/vhf/ebola/healthcare-us/evaluatingpatients/guidance-for-management-of-survivors-ebola.html. Accessed 6 Apr 2016.

64. Brett-Major DM, Jacob ST, Jacquerioz FA, et al. Being ready to treat Ebola virus disease patients. Am J Trop Med Hyg. 2015;92(2):233-7.

65. Dunser MW, Festic E, Dondorp A, et al. Recommendations for sepsis management in resource-limited settings. Intensive Care Med. 2012;38(4):557-74.

66. Maitland K, Kiguli S, Opoka RO, et al. Mortality after fluid bolus in African children with severe infection. N Engl J Med. 2011;364(26):2483-95.

67. Andrews B, Muchemwa L, Kelly P, et al. Simplified severe sepsis protocol: a randomized controlled trial of modified early goal-directed therapy in Zambia. Crit Care Med. 2014;42(11):2315-24.

68. Kortepeter MG, Lawler JV, Honko A, et al. Real-time monitoring of cardiovascular function in rhesus macaques infected with Zaire ebolavirus. J Infect Dis. 2011;204 Suppl 3:S1000-10.

69. Roberts I, Perner A. Ebola virus disease: clinical care and patient-centred research. Lancet. 2014;384(9959):2001-2.

70. Perner A, Fowler RA, Bellomo R, et al. Ebola care and research protocols. Intensive Care Med. 2015:41(1):111-4

71. Chertow DS, Uyeki TM, DuPont HL. Loperamide therapy for voluminous diarrhea in Ebola virus disease. J Infect Dis. 2015;211(7):1036-7.

72. Rees PS, Lamb LE, Nicholson-Roberts TC, et al. Safety and feasibility of a strategy of early central venous catheter insertion in a deployed UK military Ebola virus disease treatment unit. Intensive Care Med. 2015;41(5):735-43.

73. Paterson ML, Callahan CW. The use of intraosseous fluid resuscitation in a pediatric patient with Ebola virus disease. J Emerg Med. 2015;49(6):962-4.

74. Lamontagne F, Clement C, Fletcher T, et al. Doing today's work superbly well —-treating Ebola with current tools. N Engl J Med. 2014;371(17):1565-6.

75. Murthy S. Ebola Clinical Care authors group. Ebola and provision of critical care. Lancet. 2015:385(9976):1392-3.

76. Lyon GM, Mehta AK, Varkey JB, et al. Clinical care of two patients with Ebola virus disease in the United States. N Engl J Med. 2014;371(25):2402-9.

77. Parra JM, Salmeron OJ, Velasco M. The first case of Ebola virus disease acquired outside Africa. N Engl J Med. 2014;371(25):2439-40.

78. Connor Jr MJ, Kraft C, Mehta AK, et al. Successful delivery of RRT in Ebola virus disease. J Am Soc Nephrol. 2015;26(1):31-7.

79. Kraft CS, Hewlett AL, Koepsell S, et al. The use of TKM-100802 and convalescent plasma in 2 patients with Ebola virus disease in the United States. Clin Infect Dis. 2015;61(4):496-502

80. Rubin EJ, Baden LR. Out of Africa_caring for patients with Ebola. N Engl J Med. 2014:371(25):2430-2.

81. Liddell AM, Davey Jr RT, Mehta AK, et al. Characteristics and clinical management of a cluster of 3 patients with Ebola virus disease, including the first domestically acquired cases in the United States. Ann Intern Med. 2015;163(2):81-90.

82. Sueblinvong $V$, Johnson DW, Weinstein $G$ L, et al. Critical care for multiple organ failure secondary to Ebola virus disease in the United States. Crit Care Med. 2015:43(10):2066-75.

83. Stephens DS, Ribner BS, Gartland BD, et al. Ebola virus disease: experience and decision making for the first patients outside of Africa. PLoS Med. 2015; 12(7):e1001857. 
84. Boggild AK, Esposito DH, Kozarsky PE, et al. Differential diagnosis of illness in travelers arriving from Sierra Leone, Liberia, or Guinea: a cross-sectional study from the GeoSentinel Surveillance Network. Ann Intern Med. 2015;162(11):757-64.

85. Tan KR, Cullen KA, Koumans EH, et al. Inadequate diagnosis and treatment of malaria among travelers returning from Africa during the Ebola epidemic_United States, 2014-2015. MMWR Morb Mortal Wkly Rep. 2016;65(2):27-9.

86. Decker BK, Sevransky JE, Barrett K, et al. Preparing for critical care services to patients with Ebola. Ann Intern Med. 2014;161(11):831-2.

87. Halpern SD, Emanuel EJ. Ethical guidance on the use of life-sustaining therapies for patients with Ebola in developed countries. Ann Intern Med. 2015;162(4):304-5.

88. Torabi-Parizi P, Davey Jr RT, Suffredini AF, et al. Ethical and practical considerations in providing critical care to patients with Ebola virus disease. Chest. 2015;147(6):1460-6.

89. Canadian Critical Care Society, Canadian Association of Emergency Physicians, Association of Medical Microbiology \& Infectious Diseases Canada. Ebola Clinical Care Guidelines: A guide for clinicians in Canada, Report \#2. 2014. Organized by the Public Health Agency of Canada. http://www.canadiancriticalcare.org/_assets/ Ebola\%20Clinical\%20Care\%20Guidelines_ENG.pdf. Accessed 7 Sept 2015.

90. Friedrich BM, Trefry JC, Biggins JE, et al. Potential vaccines and postexposure treatments for filovirus infections. Viruses. 2012;4(9):1619-50.

91. Bishop BM. Potential and emerging treatment options for Ebola virus disease. Ann Pharmacother. 2015;49(2):196-206.

92. WHO. WHO Ebola R\&D Effort—vaccines, therapies, diagnostics. http://www.who. int/medicines/ebola-treatment/ebola_r_d_effort/en. Accessed 27 Sep 2015.

93. WHO. Potential new Ebola therapies and vaccines. Geneva, Switzerland: WHO; 2014.

94. ClincalTrials.gov. Studies of convalescent plasma use in Ebola Virus Disease. https://clinicaltrials.gov/ct2/results?term=convalescent+plasma+ebola\& Search=Search. Accessed 7 Sep 2015

95. ClincalTrials.gov. An open-label, multicenter study of the safety and anti viral activity of brincidofovir (BCV, CMX001) for Ebola Virus Disease. NCT02271347. https:/www.clinicaltrials.gov/ct2/show/NCT0227-1347. Accessed 27 Dec 2014.

96. PanAfricanClinicalTrialsRegistry. Rapid assessment of potential interventions \& drugs for Ebola (RAPIDE) -TKM. http://www.pactr.org/ATMWeb/ appmanager/atm/atmregistry?_nfpb=true\&_windowLabel= BasicSearchUpdateController_1\&BasicSearchUpdateController_1_ actionOverride $=\% 2$ Fpageflows\%2Ftrial\%2FbasicSearchUpdate $\% 2$ FviewTrail\&BasicSearchUpdateController. Accessed 23 Sep 2015.

97. Sissoko D, Laouenan C, Folkesson E, et al. Experimental treatment with favipiravir for Ebola virus disease (the JIKI trial): a historically controlled, single-arm proof-of-concept trial in Guinea. PLoS Med. 2016;13(3):e1001967.

98. Mupapa K, Massamba M, Kibadi K, et al. Treatment of Ebola hemorrhagic fever with blood transfusions from convalescent patients. International Scientific and Technical Committee. J Infect Dis. 1999;179 Suppl 1:S18-23.

99. Florescu DF, Kalil AC, Hewlett AL, et al. Administration of brincidofovir and convalescent plasma in a patient with Ebola virus disease. Clin Infect Dis. 2015;61(6):969-73.

100. Takada A, Ebihara $H$, Jones $S$, et al. Protective efficacy of neutralizing antibodies against Ebola virus infection. Vaccine. 2007;25(6):993-9.

101. Marzi A, Yoshida R, Miyamoto $H$, et al. Protective efficacy of neutralizing monoclonal antibodies in a nonhuman primate model of Ebola hemorrhagic fever. PLoS One. 2012;7(4):e36192.

102. van Griensven J, Edwards T, de Lamballerie X, et al. Evaluation of convalescent plasma for Ebola virus disease in Guinea. N Engl J Med. 2016;374(1):33-42.

103. Oestereich L, Ludtke A, Wurr S, et al. Successful treatment of advanced Ebola virus infection with T-705 (favipiravir) in a small animal model. Antiviral Res. 2014;105:17-21.

104. ClincalTrials.gov. Efficacy of favipiravir against Ebola (JIKI). NCT02329054. Available from: https://clinicaltrials.gov/ct2/show/NCT02329054. Accessed 7 Sep 2015.

105. Sissoko D, Folkesson E, Abdoul M, et al. Favipiravir in patients with Ebola virus disease: early results of the JIKI trial in Guinea. In: Conference on Retroviruses and Opportunistic Infections. Seattle, USA: IAS-USA/CROI Foundation; 2015. http://www.croiconference.org/sessions/favipiravir-patients-ebola-virusdisease-early-results-jiki-trial-guinea. Accessed 7 Sept 2015.

106. Chimerix, Inc. Brincidofovir. http://www.chimerix.com/discovery-clinicaltrials/brincidofovir/brincidofovir-for-ebola. Accessed 27 Dec 2014.

107. Trust W. Wellcome Trust-funded Ebola treatment trial stopped in Liberia. http://www.wellcome.ac.uk/News/Media-office/Press-releases/2015/ WTP058609.htm, Accessed 7 Sep 2015.
108. Geisbert TW, Lee AC, Robbins M, et al. Postexposure protection of non-human primates against a lethal Ebola virus challenge with RNA interference: a proof-of-concept study. Lancet. 2010;375(9729):1896-905.

109. Dunning J, Sahr F, Rojek A, Gannon F, Carson G, Idriss B, Massaquoi T, Gandi R, Joseph S, Osman HK, Brooks TJ, Simpson AJ, Goodfellow I, Thorne L, Arias A, Merson L, Castle L, Howell-Jones R, Pardinaz-Solis R, Hope-Gill B, Ferri M, Grove J, Kowalski M, Stepniewska K, Lang T, Whitehead J, Olliaro P, Samai M, Horby PW; RAPIDE-TKM trial team. Experimental Treatment of Ebola Virus Disease with TKM-130803: A Single-Arm Phase 2 Clinical Trial. PLoS Med. 2016 Apr 19;13(4):e1001997. doi:10.1371/journal.pmed.1001997.

110. Qiu X, Wong G, Audet J, et al. Reversion of advanced Ebola virus disease in nonhuman primates with ZMapp. Nature. 2014;514(7520):47-53.

111. Goodman JL. Studying "secret serums"—-toward safe, effective Ebola treatments. N Engl J Med. 2014;371(12):1086-9.

112. Davey RTftM-NPIST, NIAID, NIH, Bethesda, MD, USA. PREVAIL II: a randomized controlled trial of ZMapp ${ }^{\mathrm{TM}}$ in acute Ebola virus infection. In: Conference on Retroviruses and Opportunistic Infections (CROI). Boston, Massachusetts, USA: IAS-USA/CROI Foundation; 2016. http://www. croiconference.org/sessions/prevail-ii-randomized-controlled-trial-zmapp ${ }^{\mathrm{TM}}$ acute-ebola-virus-infection. Accessed 23 Feb 2016.

113. Dodd LE, Proschan MA, Neuhaus J, Koopmeiners JS, Neaton J, Beigel JD, Barrett K, Lane HC, Davey RT Jr. Design of a Randomized Controlled Trial for Ebola Virus Disease Medical Countermeasures: PREVAIL II, the Ebola MCM Study. J Infect Dis. 2016 Jun 15;213(12):1906-13.

114. Gehring G, Rohrmann K, Atenchong N, et al. The clinically approved drugs amiodarone, dronedarone and verapamil inhibit filovirus cell entry. J Antimicrob Chemother. 2014;69(8):2123-31.

115. Fedson DS, Jacobson JR, Rordam OM, et al. Treating the host response to Ebola virus disease with generic statins and angiotensin receptor blockers. MBio. 2015;6(3):e00716.

116. Gignoux E, Azman AS, de Smet M, et al. Effect of artesunate-amodiaquine on mortality related to Ebola virus disease. N Engl J Med. 2016;374(1):23-32.

117. Stanley DA, Honko AN, Asiedu C, et al. Chimpanzee adenovirus vaccine generates acute and durable protective immunity against ebolavirus challenge. Nat Med. 2014;20(10):1126-9.

118. Geisbert TW, Geisbert JB, Leung A, et al. Single-injection vaccine protects nonhuman primates against infection with marburg virus and three species of Ebola virus. J Virol. 2009:83(14):7296-304.

119. Agnandji ST, Huttner A, Zinser ME, et al. Phase 1 trials of rVSV Ebola vaccine in Africa and Europe_-preliminary report. N Engl J Med. 2016;374(17):1647-1660.

120. Henao-Restrepo AM, Longini IM, Egger M, et al. Efficacy and effectiveness of an rVSV-vectored vaccine expressing Ebola surface glycoprotein: interim results from the Guinea ring vaccination cluster-randomised trial. Lancet. 2015;386(9996):857-66.

121. De Santis O, Audran R, Pothin E, et al. Safety and immunogenicity of a chimpanzee adenovirus-vectored Ebola vaccine in healthy adults: a randomised, double-blind, placebo-controlled, dose-finding, phase 1/2a study. Lancet Infect Dis. 2016;16(3):311-320.

122. Sarwar UN, Costner $P$, Enama ME, Berkowitz N, Hu Z, Hendel CS, Sitar S, Plummer S, Mulangu S, Bailer RT, Koup RA, Mascola JR, Nabel GJ, Sullivan NJ, Graham BS, Ledgerwood JE; VRC 206 Study Team. Safety and immunogenicity of DNA vaccines encoding Ebolavirus and Marburgvirus wild-type glycoproteins in a phase I clinical trial. J Infect Dis. 2015;211(4): 549-57.

123. Milligan ID, Gibani MM, Sewell R, et al. Safety and Immunogenicity of Novel Adenovirus Type 26- and Modified Vaccinia Ankara-Vectored Ebola Vaccines: A Randomized Clinical Trial. JAMA. 2016;315(15):1610-1623.

124. Wong KK, Davey RT Jr, Hewlett AL, Kraft CS, Mehta AK, Mulligan MJ, Beck A, Dorman W, Kratochvil CJ, Lai L, Palmore TN, Rogers S, Smith PW, Suffredini AF, Wolcott M, Ströher U, Uyeki TM. Use of Postexposure Prophylaxis After Occupational Exposure to Zaire ebolavirus. Clin Infect Dis. 2016 Apr 26. pii: ciw256. [Epub ahead of print].

125. Jacobs M, Aarons E, Bhagani S, Buchanan R, Cropley I, Hopkins S, Lester R, Martin D, Marshall N, Mepham S, Warren S, Rodger A. Post-exposure prophylaxis against Ebola virus disease with experimental antiviral agents: a case-series of health-care workers. Lancet Infect Dis. 2015;15(11):1300-4.

126. Lai L, Davey R, Beck A, Xu Y, Suffredini AF, Palmore T, Kabbani S, Rogers S, Kobinger G, Alimonti J, Link CJ Jr, Rubinson L, Ströher U, Wolcott M, Dorman W, Uyeki TM, Feldmann H, Lane HC, Mulligan MJ. Emergency postexposure vaccination with vesicular stomatitis virus-vectored Ebola vaccine after needlestick. JAMA. 2015;313(12):1249-55. 
127. Nanyonga M, Saidu J, Ramsay A, et al. Sequelae of Ebola virus disease, Kenema District, Sierra Leone. Clin Infect Dis. 2016;62(1):125-6.

128. Epstein L, Wong KK, Kallen AJ, et al. Post-Ebola signs and symptoms in U.S. survivors. N Engl J Med. 2015;373(25):2484-6.

129. Qureshi Al, Chughtai M, Loua TO, et al. Study of Ebola virus disease survivors in Guinea. Clin Infect Dis. 2015;61(7):1035-42.

130. Clark DV, Kibuuka H, Millard M, et al. Long-term sequelae after Ebola virus disease in Bundibugyo, Uganda: a retrospective cohort study. Lancet Infect Dis. 2015;15(8):905-12.

131. Mattia JG, Vandy MJ, Chang JC, et al. Early clinical sequelae of Ebola virus disease in Sierra Leone: a cross-sectional study. Lancet Infect Dis. 2016;16(3):331-338.

132. Vetter P, Kaiser L, Schibler M, et al. Sequelae of Ebola virus disease: the emergency within the emergency. Lancet Infect Dis. 2016. doi:10.1016/ S1473-3099(16)00077-3, http://www.sciencedirect.com/science/article/pii/ S1473309916000773.

133. Lee-Kwan SH, DeLuca N, Adams M, et al. Support services for survivors of ebola virus disease-Sierra Leone, 2014. MMWR Morb Mortal Wkly Rep. 2014;63(50):1205-6.

134. WHO. Sierra Leone: Helping the Ebola survivors turn the page. http://www. who.int/features/2014/post-ebola-syndrome/en. Accessed 7 Jul 2015.

135. WHO. A story of Ebola survival and return. http://www.who.int/tdr/news/ 2014/ebola-survival-return/en. Accessed 5 Sept 2015.

136. Schoepp RJ, Rossi CA, Khan SH, et al. Undiagnosed acute viral febrile illnesses. Sierra Leone Emerg Infect Dis. 2014;20(7):1176-82.

137. CNN. American Ebola patient released from Nebraska hospital. http://www. cnn.com/2014/09/25/health/ebola-american-patient. Accessed 27 Sep 2015. 